\title{
Pengaruh Suhu dan Konsentrasi Larutan Gula Terhadap Proses Dehidrasi Osmosis Bengkuang (Pachyrhizus erosus)
}

\section{(Effect of Temperature and Concentration of Sugar Solution in The Process of Osmotic Dehydration of Jicama (Pachyrhizus erosus))}

\author{
Reski Ramadhani Rum ${ }^{* 1)}$, Supratomo'), dan Mursalim ${ }^{3)}$ \\ ${ }^{1)}$ Program Studi Keteknikan Pertanian Universitas Hasanuddin \\ 2) Program Studi Keteknikan Pertanian Universitas Hasanuddin \\ 3) Program Studi Keteknikan Pertanian Universitas Hasanuddin \\ Email korespondensi: kikirum21@gmail.com
}

\begin{abstract}
ABSTRAK
Bengkuang merupakan salah satu tanaman umbi-umbian yang memiliki kandungan kadar air yang tinggi. Diketahui bengkuang memiliki kadar air $86-90 \%$ yang menyebabkan bengkuang mudah rusak dan ditumbuhi jamur sehingga masa simpannya singkat padahal memiliki potensi industri yang cukup besar. Dehidrasi osmosis merupakan teknik pengurangan kadar air yang dapat digunakan untuk mengatasi permasalahan tersebut yaitu dengan cara perendaman bahan pada larutan berkonsentrasi tinggi. Penelitian ini dilaksanakan pada bulan Agustus 2018 sampai bulan Oktober 2018 di Laboratorium Pengolahan Pangan dan Analisis Kimia Universitas Hasanuddin. Tujuan penelitian ini yaitu untuk mengetahui pengaruh suhu dan konsentrasi larutan gula terhadap kadar air akhir, penurunan bobot (WR), jumlah padatan yang masuk (SG), jumlah air yang keluar dari bahan (WL) pada bengkuan selama proses dehidrasi osmosis dan mengetahui suhu dan konsentrasi yang optimal dalam proses dehidrasi bengkuang. Metode yang digunakan pada penelitian ini adalah dengan menggunakan rancangan acak lengkap yang disusun secara factorial dengan 2 faktor dan masing-masing faktor terdiri atas 3 level yaitu kadar gula 50 Brix, 60 Brix, 70 Brix dan suhu perendaman $30^{\circ} \mathrm{C}, 40^{\circ} \mathrm{C}, 50^{\circ} \mathrm{C}$ dengan 3 kali ulangan. Berdasarkan hasil penelitian didapatkan bahwa perlakuan suhu $50^{\circ} \mathrm{C}$ dan konsentrasi larutan 70 Brix menghasilkan kadar air yang paling rendah yakni 33,8\% basis basah dan mempunyai peningkatan nilai Solid Gain paling tinggi dengan nilai 1,0234 g namun suhu perendaman dan konsentrasi larutan tidak memberikan pengaruh pada peningkatan Weight Reduction dan Water Loss.
\end{abstract}

Kata Kunci: Dehidrasi Osmosis, Suhu, Konsentrasi Larutan, Bengkuang

\section{PENDAHULUAN}

\section{Latar Belakang}

Bengkuang dikategorikan oleh IPGRI (international Plant Genetic Resources Insstitute) sebagai salah satu tanaman yang terabaikan dan belum termanfaatkan, adalah salah satu tanaman legum neotropics yang menghasilkan ubi akar yang dapat dikonsumsi. Sejauh ini bengkuang di Indonesia hanya dimanfaatkan sebagai bahan konsumsi segar padahal sebenarnya memiliki potensi industri yang cukup besar.

Tumbuhan bengkuang membentuk umbi akar (cormus) berbentuk bulat atau membulat seperti gasing dengan berat dapat mencapai $5 \mathrm{~kg}$. Kulit umbinya tipis berwarna kuning pucat dan bagian dalamnya berwarna putih dengan cairan 
segar agak manis. Umbinya mengandung gula dan pati serta fosfor dan kalsium. Umbi ini juga memiliki efek pendingin karena mengandung kadar air 86-90\%. Rasa manis berasal dari suatu oligosakarida yang disebut inulin, yang tidak bisa dicerna tubuh manusia (Wongsowijoyo, 2014).

Bengkuang memiliki kandungan air yang cukup tinggi. Hal ini menyebabkan bengkuang mudah ditumbuhi jamur dan bakteri yang dapat merusak dan menurunkan daya simpannya. Untuk mengatasi hal tersebut, salah satu metodennya dengan melakukan pengeringan dengan metode osmosis.

Osmotic dehydration (OD) adalah operasi yang digunakan untuk menghilangkan sebagian air dari jaringan tanaman dengan pencelupan dalam larutan hipertonik, gula atau larutan garam, untuk pmengurangi kadar air makanan. Teknik ini adalah proses dehidrasi parsial untuk memberikan peningkatan kualitas produk atas proses pengeringan konvensional. Dehidrasi osmotik dipengaruhi oleh beberapa faktor seperti agen osmotik, konsentrasi zat terlarut, suhu, waktu, ukuran, dan bentuk dan kekompakan jaringan bahan, agitasi dan rasio larutan/sampel. Teknik ini membantu menghemat energi keseluruhan relatif terhadap prosedur pengeringan lainnya (Akbarian, 2014).

Berdasarkan penjelasan di atas, maka dilakukannya penelitian tentang pengaruh suhu dan konsentrasi larutan terhadap proses dehidrasi osmosis dan mengetahui suhu dan konsentrasi yang optimal untuk proses dehidrasi osmosis.

\section{Tujuan Penelitian}

Tujuan dari penelitian ini adalah untuk mengetahui pengaruh suhu dan konsentrasi larutan gula pada bengkuang selama proses dehidrasi osmosis, dan mengetahui suhu dan konsentrasi larutan yang optimal dalam proses dehidrasi osmosis bengkuang.

\section{METODOLOGI PENELITIAN}

\section{Alat}

Alat yang digunakan pada penelitian ini adalah water bath, oven, desikator, gelas breaker $2 \mathrm{~L}$, sendok, timbangan analitik, wadah plastik, termometer, pisau dan talenan.

\section{Bahan}

Bahan yang digunakan pada penelitian ini adalah bengkuang, gula, aquades, plastik, tissue roll, kertas label dan aluminium foil.

\section{Prosedur Penelitian}

Rancangan penelitian yang digunakan adalah Rancangan Acak Lengkap Faktorial yang terdiri atas 2 faktor. Masing-masing faktor terdiri atas 3 level dengan 3 kali ulangan. Faktor tersebut adalah:

Faktor I : Kadar gula

$\mathrm{K} 1=50$ Brix

$\mathrm{K} 2=60$ Brix

$\mathrm{K} 3=70$ Brix

Faktor II: Suhu perendaman

$$
\begin{aligned}
\mathrm{T} 1 & =30^{\circ} \mathrm{C} \\
\mathrm{T} 2 & =40^{\circ} \mathrm{C} \\
\mathrm{T} 3 & =50^{\circ} \mathrm{C}
\end{aligned}
$$

a. Jika analisis varian ada interaksi antara konsentrasi gula dengan suhu perendaman maka dilakukan uji Duncan

b. Jika tidak ada interaksi maka masingmasing perlakuan diuji tersendirisendiri.

Prosedur kerja dari penelitian ini adalah:

a. Penyiapan Larutan Osmosis

Adapun tahap-tahap dalam menyiapkan larutan osmosis yakni, sebagai berikut (Kartika, 2015):

1. Menyiapkan alat dan Bahan

2. Menimbang gula sebanyak 1000g, $1200 \mathrm{~g}$, dan 1400g dengan menambahkan air sebanyak $1000 \mathrm{ml}$, $800 \mathrm{ml}$, dan $600 \mathrm{ml}$.

3. Memasukkan gula ke dalam panci. 
4. Memasak larutan gula pada suhu $80^{\circ} \mathrm{C}$ selama 4 menit, dilakukan proses pengadukan hingga padatan gula terlarut seluruhnya.

5. Memastikan konsentrasi pada larutan telah sesuai, dengan menggunakan refraktometer.

6. Memasukkan hasil larutan ke dalam wadah untuk dilakukan pendinginan selama 1 jam atau lebih pada suhu ruang.

b. Penyiapan Sampel

Adapun tahap-tahap dalam menyiapkan sampel yakni, sebagai berikut (Sharma, 2000):

1. Mengupas kulit bengkuang, mencuci dan memotong bengkuang dengan berat masing-masing \pm 5 gram .

2. Memberi tanda pada masing-masing sampel.

3. Meletakkan hasil potongan bengkuang pada wadah dan menutupnya dengan plastik.

c. Proses dehidrasi osmosis

$$
\text { Adapun tahap-tahap dalam }
$$

perendaman sampel dengan larutan gula yakni, sebagai berikut (Sharma, 2000):

1. Memasukkan 2 L larutan osmosis 50 Brix ke dalam gelas breaker.

2. Memasukkan 20 potongan sampel ke dalam larutan osmosis 50 Brix. Lalu, larutan ditutup dengan aluminium foil, untuk mencegah air masuk kedalam gelas kimia selama proses berlangsung.

3. Memasukkan gelas breaker yang berisi larutan dan sampel ke dalam sebuah water bath, yang dipertahanakan pada suhu $40^{\circ} \mathrm{C}$.

4. Mengambil satu sampel, setiap interval waktu $20 \quad$ menit sampai 3 jam.

5. Menimbang dan mencatat sampel yang telah direndam.

6. Mengeringkan sampel dengan oven selama 24 jam atau sampai konstan dengan suhu $105^{\circ} \mathrm{C}$.

7. Mengulangi prosedur 1 sampai 5 dengan suhu $50^{\circ} \mathrm{C}$ dan $60^{\circ} \mathrm{C}$ serta pengulangan dengan konsentrasi 60

Brix dan 70 Brix.

\section{Parameter Penelitian}

a. Kadar air Akhir

Pengukuran kadar air dilakukan dengan metode gravimetrik/oven yaitu dilakukan dengan memasukkan sampel sebelum perendaman kedalam cawan yang telah ditimbang untuk mendapatkan data berat awal $\left(\mathrm{W}_{0 \mathrm{x}}\right)$. Setelah itu, dimasukkan dalam oven hingga bobot konstan selama 24 jam pada suhu $105^{\circ} \mathrm{C}$. Lalu, bahan dikeluarkan dan dimasukkan kedalam desikator selama 15 menit $\left(\mathrm{W}_{\mathrm{x}}\right)$. Data yang diperoleh, kemudian diolah dengan rumus dibawah:

Keterangan:

$$
\mathrm{Mx}=\frac{\mathrm{W} 0 \mathrm{x}-\mathrm{Wx}}{\mathrm{W} 0 \mathrm{x}} \times 100 \%
$$

Mx : Kadar air basis basah pada sampel $\mathrm{x}(\%)$.

W0x : Berat sampel $\mathrm{x}$ awal bengkuang pada waktu $\mathrm{t}=0(\mathrm{~g})$.

Wx : Berat sampel $\mathrm{x}$ kering pada waktu $\mathrm{t}$ (g)

b. Penurunan Bobot (WR)

Mengambil sampel data awal sebelum perendaman $\left(\mathrm{W}_{0 \mathrm{x}}\right)$ dan data berat sampel kering sebelum perendaman $\left(\mathrm{S}_{0 \mathrm{x}}\right)$. Kemudian sampel yang telah direndam, diambil dan ditiriskan. Kemudian, diletakkan pada cawan dan ditimbang $\left(\mathrm{W}_{\mathrm{x}}\right)$.

Keterangan:

$$
\mathrm{WRx}=\frac{\mathrm{W} 0 \mathrm{x}-\mathrm{Wx}}{\mathrm{S} 0 \mathrm{x}}
$$

WRx : Penurunan bobot sampel x (g).

$\mathrm{W}_{0 \mathrm{x}}$ : Berat sampel x pada waktu $\mathrm{t}=0(\mathrm{~g})$.

$\mathrm{W}_{\mathrm{x}}$ : Berat sampel $\mathrm{x}$ setelah perendaman pada waktu $\mathrm{t}(\mathrm{g})$.

$\mathrm{S}_{0 \mathrm{x}} \quad$ : Berat kering sampel $\mathrm{x}$ sebelum perendaman $(\mathrm{g})$.

c. Padatan terlarut yang masuk dalam bahan (SG)

Menimbang sampel kering sebelum perendaman $\left(\mathrm{S}_{0 \mathrm{x}}\right)$, dan sampel yang telah direndam pada waktu $\mathrm{t}$, dikeringkan hingga bobot konstan selama 24 jam pada suhu $105^{\circ} \mathrm{C}\left(\mathrm{S}_{\mathrm{x}}\right)$. Data yang telah diperoleh 
kemudian dilakukan perhitungan sebagai berikut:

Keterangan:

$$
\mathrm{SGx}=\frac{\mathrm{Sx}-\mathrm{S} 0 \mathrm{x}}{\mathrm{S} 0 \mathrm{x}}
$$

SGx : Solid gain waktu $\mathrm{t}(\mathrm{g})$.

S0x : Berat kering sampel $\mathrm{x}$ sebelum perendaman $(\mathrm{g})$.

Sx : Berat kering sampel $\mathrm{x}$ setelah perendaman pada waktu $\mathrm{t}(\mathrm{g})$.

d. Jumlah air yang keluar dari bahan (WL)

Jumlah air yang keluar dari bahan dapat dihitung menggunakan data-data yang telah diolah yakni jumlah air yang keluar dari bahan $\left(\mathrm{WR}_{\mathrm{x}}\right)$ dan padatan terlarut yang masuk dalam bahan $\left(\mathrm{SG}_{\mathrm{x}}\right)$. kemudian dianalisis dengan perhitungan sebagai berikut:

Keterangan:

$$
\mathrm{WL}_{\mathrm{x}}=\mathrm{WR}_{\mathrm{x}}+\mathrm{SG}_{\mathrm{x}}
$$

WLx : Jumlah air yang keluar dari bahan pada sampel x (g).

WRx : Penurunan bobot pada sampel $\mathrm{x}(\mathrm{g})$

SGx : Padatan terlarut yang masuk dalam bahan pada sampel x (g).

\section{Bagan Alir Penelitian}

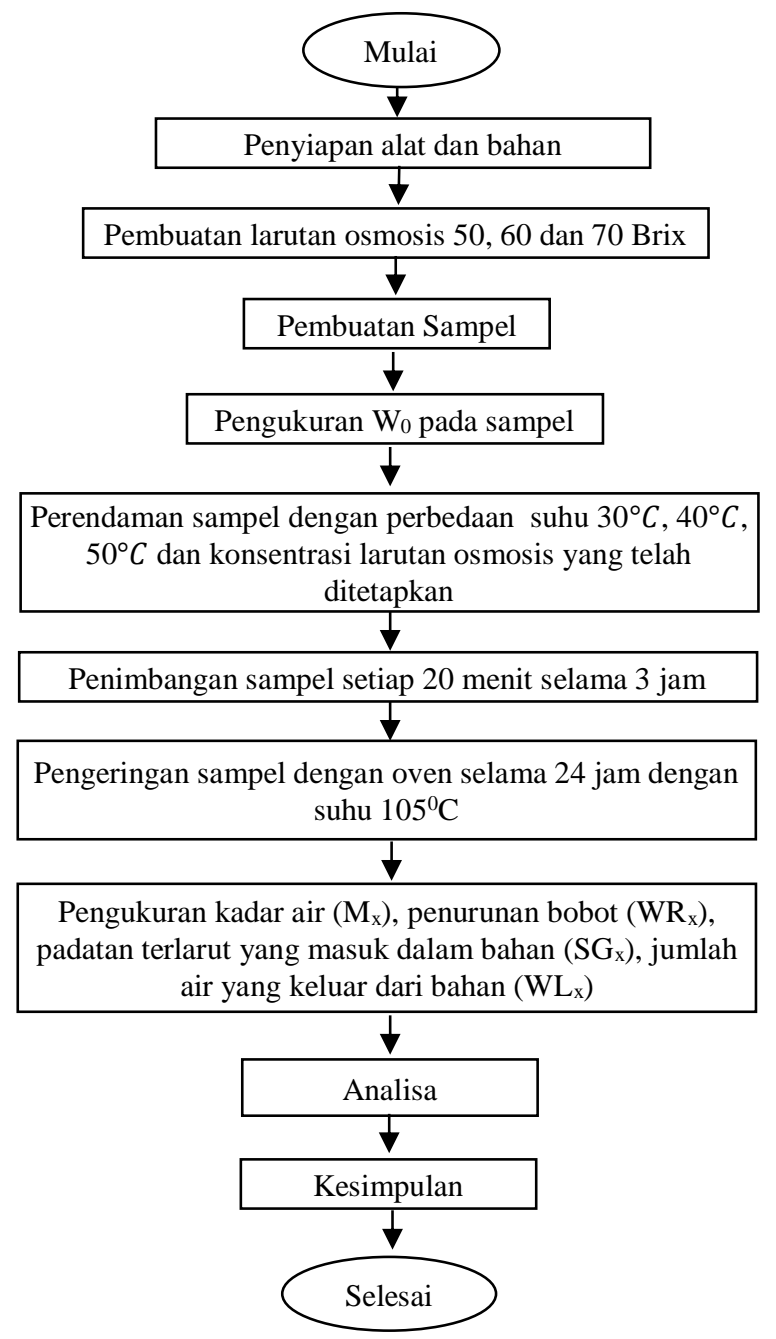

\section{Gambar 1. Diagram Alir Penelitian}

HASIL DAN PEMBAHASAN

\section{Deskripsi Sampel}

Bahan yang digunakan dalam penelitian ini adalah bengkuang dengan ukuran rata-rata $1 \mathrm{~kg}$ yang diperoleh di pasar Pabaeng-baeng, kecamatan Tamalate, Makassar, yang telah disimpan selama 3-5 hari setelah pemanenan. Dalam penelitian yang dilakukan, bengkuang dikupas kulitnya kemudian dipotong dengan berat masing-masing \pm 5 gram dengan tebal $\pm 0.5 \mathrm{~cm}$.

\section{Perubahan Kadar Air}

a. Hasil Penelitian untuk Perubahan Kadar Air Akhir

Kadar air merupakan banyaknya air yang terkandung dalam bahan yang dinyatakan dalam persen. Adapun tabel hasil perubahan kadar air yang didapatkan dari hasil pengolahan data awal seperti pada tabel di bawah:

Tabel 1. Hasil penelitian untuk pengukuran kadar air akhir

\begin{tabular}{ccccr}
$\begin{array}{c}\text { Suhu } \\
\text { Perendaman } \\
\left({ }^{\circ} \mathrm{C}\right)\end{array}$ & \multicolumn{2}{c}{ Konsentrasi Larutan (Brix) } & Rata- \\
\cline { 2 - 4 } & 50 & 60 & 70 & Rata \\
\hline 30 & 62,158 & 64,690 & 60,975 & 62,608 \\
40 & 62,257 & 54,713 & 49,856 & 55,609 \\
50 & 56,120 & 44,860 & 33,809 & 44,930 \\
\hline Rata-Rata & 60,178 & 54,754 & 48,213 & \\
\hline
\end{tabular}

Dari tabel hasil penelitian untuk perubahan kadar air akhir menunjukkan bahwa kadar air akhir yang paling rendah berada pada kombinasi perlakuan suhu perendaman $50^{\circ} \mathrm{C}$ dan konsentrasi larutan 70 Brix. Dan kadar air akhir yang paling tinggi pada kombinasi perlakuan suhu perendaman $30^{\circ} \mathrm{C}$ dan konsentrasi larutan 50 Brix. Hal tersebut terjadi karena semakin tinggi suhu perendaman dan semakin tinggi konsentrasi larutan yang digunakan maka kadar air akhir yang dihasilkan akan semakin rendah. Hal ini sesuai dengan pendapat Chavan (2012), proses dehidrasi osmosis yang ditetapkan pada suhu $50^{\circ} \mathrm{C}$ yang direndam dalam waktu 3 jam memberikan kehilangan air 
optimal dan masuknya gula ke dalam bahan optimal.

\section{b. Analisis Ragam untuk Kadar Air Akhir}

Berdasarkan hasil uji analisis ragam pada taraf 5\% untuk kadar air akhir menunjukkan bahwa ada interaksi antara konsentrasi larutan gula dan suhu perendaman dan memberikan pengaruh yang nyata terhadap perubahan kadar air. Hal tersebut dilihat dari nilai signifikan suhu dan konsentrasi yang didapatkan yaitu 0,001 (Lampiran Tabel 20). Hal ini sesuai dengan pendapat Chavan (2010), bahwa kehilangan air dan gula peningkatannya linier dengan peningkatan suhu dan konsentrasi gula. Konsentrasi gula dan suhu berfungsi dalam peningkatan defuse gula. Secara umum, larutan gula dengan konsentrasi 60 sampai 70 Brix adalah konsentrasi yang optimal dalam proses dehidrasi osmosis.

Berdasarkan hasil interaksi yang telah didapatkan bahwa nilai selisih dari kombinasi perlakuan yang nilainya lebih besar dari LSR yaitu suhu $30{ }^{\circ} \mathrm{C}$ konsentrasi 60 Brix berbeda nyata dengan kombinasi suhu $50^{\circ} \mathrm{C}$ dan konsentrasi 50 Brix, suhu $40^{\circ} \mathrm{C}$ dan konsentrasi 60 konsentrasi Brix , suhu $40{ }^{\circ} \mathrm{C}$ dan konsentrasi 70 Brix, suhu $50{ }^{\circ} \mathrm{C}$ dan konsentrasi 60 Brix, dan suhu $50{ }^{\circ} \mathrm{C}$ dan konsentrasi 70 Brix. Kombinasi perlakuan suhu $40^{\circ} \mathrm{C}$ dan konsentasi 50 Brix berbeda nyata dengan kombinasi suhu $40{ }^{\circ} \mathrm{C}$ dan 60 Brix, suhu $40^{\circ} \mathrm{C}$ dan konsentrasi $70 \mathrm{Bix}$, suhu $50^{\circ} \mathrm{C}$ dan konsentrasi 60 Brix, dan suhu $50^{\circ} \mathrm{C}$ dan konsentrasi 70 Brix. Kombinasi suhu $30^{\circ} \mathrm{C}$ dan konsentrasi 50 Brix berbeda nyata dengan kombinasi suhu $40{ }^{\circ} \mathrm{C}$ dan konsentrasi 60 Brix, suhu $40{ }^{\circ} \mathrm{C}$ dan konsentrasi 70 Brix, suhu $50^{\circ} \mathrm{C}$ dan konsentrasi 60 Brix dan $50{ }^{\circ} \mathrm{C}$ dan konsentrasi 70 Brix. Kombinasi perlakuan suhu $30^{\circ} \mathrm{C}$ dan konsentrasi 70 Brix berbeda nyata dengan kombinasi suhu $40{ }^{\circ} \mathrm{C}$ dan konsentrasi $70 \mathrm{Bix}$, suhu $50^{\circ} \mathrm{C}$ dan konsentrasi 60 Brix dan $50{ }^{\circ} \mathrm{C}$ dan konsentrasi 70 Brix. Kombinasi suhu $50{ }^{\circ} \mathrm{C}$ dan konsentrasi 50 Brix berbeda nyata dengan kombinasi suhu $50{ }^{\circ} \mathrm{C}$ dan konsentrasi 60 Brix dan $50^{\circ} \mathrm{C}$ dan konsentrasi 70 Brix. Kombinasi suhu $40{ }^{\circ} \mathrm{C}$ dan konsentrasi 70 Brix berbeda nyata dengan kombinasi suhu $50{ }^{\circ} \mathrm{C}$ dan konsentrasi 60 Brix dan $50{ }^{\circ} \mathrm{C}$ dan konsentrasi 70 Brix. Kombinasi suhu $40{ }^{\circ} \mathrm{C}$ dan konsentrasi 70 Brix berbeda nyata dengan kombinasi $50^{\circ} \mathrm{C}$ dan konsentrasi 70 Brix. Begitu pula dengan kombinasi suhu $50^{\circ} \mathrm{C}$ dan konsentrasi 60 Brix berbeda nyata dengan kombinasi $50^{\circ} \mathrm{C}$ dan konsentrasi 70 Brix. Untuk kombinasi lainnya yang tidak bergaris bawah nilai selisih yang didapatkan lebih kecil dari nilai LSR sehingga kombinasi tersebut tidak berbeda nyata.

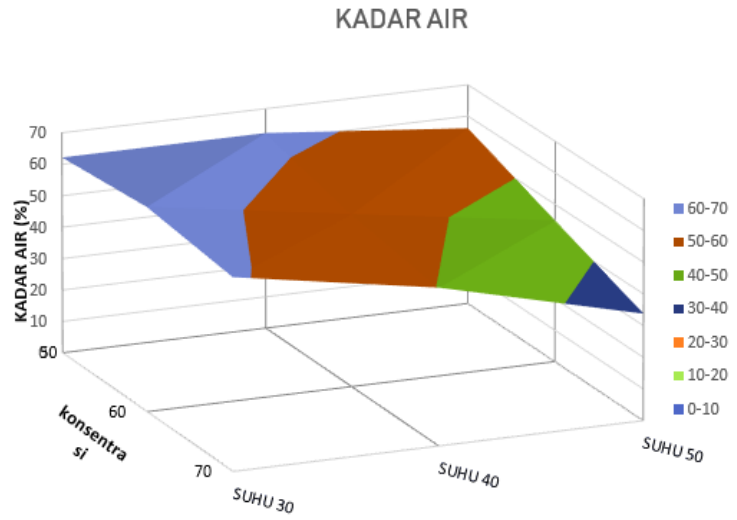

Gambar 2. Grafik Hubungan Suhu dan Konsentrasi terhadap Kadar Air

Pada gambar 2 menunjukkan bahwa pada grafik hubungan suhu dan konsentrasi terhadap kadar air akhir suhu $50^{\circ} \mathrm{C}$ penurunan kadar air yang paling banyak ada pada konsentrasi 70 Brix dengan nilai kadar air akhir 33\% yang pada grafik ditunjukkan pada bagian berwarna kuning. Sedangkan untuk kombinasi suhu $30^{\circ} \mathrm{C}$ dan konsentrasi 60 Brix menunjukkan penurunan kadar air paling sedikit dengan nilai kadar air $64 \%$. Hal ini terjadi karena proses penurunan kadar air dipengaruhi oleh suhu dan konsentrasi larutan. Semakin tinggi suhu perendaman maka semakin tinggi penurunan kadar airnya. Hal ini sesuai pendapat Tortoe (2010), bahwa suhu 
menjadi variabel penting dalam proses penurunan kadar air suatu bahan.

\section{Weight Reduction (WR)}

a. Hasil Penelitian untuk Weight Reduction (WR)

Weight reduction merupakan penurunan bobot bahan dalam proses pengurangan kadar air bahan yang dinyatakan dalam persen. Adapun Tabel hasil untuk WR, seperti pada tabel di bawah:

Tabel 2. Hasil penelitian untuk pengukuran WR

\begin{tabular}{ccccc}
\hline Suhu & \multicolumn{3}{c}{ Konsentrasi Laruran (Brix) } & \multirow{2}{*}{$\begin{array}{c}\text { Rata- } \\
\text { rata }\end{array}$} \\
\cline { 2 - 4 }$\left({ }^{\circ} \mathrm{C}\right)$ & 50 & 60 & 70 & \\
\hline 30 & 53,0459 & 55,1922 & 57,3349 & 55,1910 \\
40 & 57,7168 & 61,0415 & 64,2198 & 60,9927 \\
50 & 57,3530 & 61,3058 & 66,3497 & 61,6695 \\
\hline Rata-Rata & 56,0386 & 59,1798 & 62,6348 & \\
\hline
\end{tabular}

Berdasarkan tabel 2 hasil penelitian untuk WR menunjukkan bahwa nilai WR paling tinggi berada pada kombinasi perlakuan suhu perendaman $50^{\circ} \mathrm{C}$ dan konsentrasi larutan 70 Brix. Hal ini terjadi karena suhu perendaman dan konsentasi larutan mempengaruhi penurunan bobot. Hal ini sesuai dengan pedapat Akbarian (2014), peningkatan konsentrasi larutan osmotik menghasilkan peningkatan kehilangan air pada bahan pada tingkat pengeringan. Peningkatan konsentrasi larutan osmotik menyebabkan peningkatan pengurangan bobot.

\section{b. Analisis Ragam untuk Weight Reduction (WR)}

Berdasarkan hasil uji analisis ragam pada WR pada taraf 5\% menunjukkan bahwa tidak ada interaksi antara konsentrasi larutan gula dan suhu perendaman terhadap perubahan Weight Reduction (WR). Hal tersebut dilihat dari nilai signifikan suhu dan konsentrasi yang didapatkan yaitu 0,110 .

Setelah pengujian analisis ragam menunjukkan tidak adanya interaksi antara suhu dan konsentrasi larutan pada penurunan bobot, maka dilakukan pengujian tersendiri terhadap suhu juga konsentrasi larutan dengan uji Duncan. Setelah pengujian hasil menunjukkan bahwa pengujian Duncan pada taraf 5\% untuk konsentrasi terhadap WR diperoleh konsentrasi 50 Brix berbeda nyata dengan konsentrasi 60 dan 70 Brix. Untuk hasil pengujian Duncan pada taraf $5 \%$ pada suhu terhadap WR diperoleh untuk suhu $30{ }^{\circ} \mathrm{C}$ berbeda nyata dengan suhu $40{ }^{\circ} \mathrm{C}$ namun suhu $40^{\circ} \mathrm{C}$ tidak berbeda nyata dengan suhu $50^{\circ} \mathrm{C}$

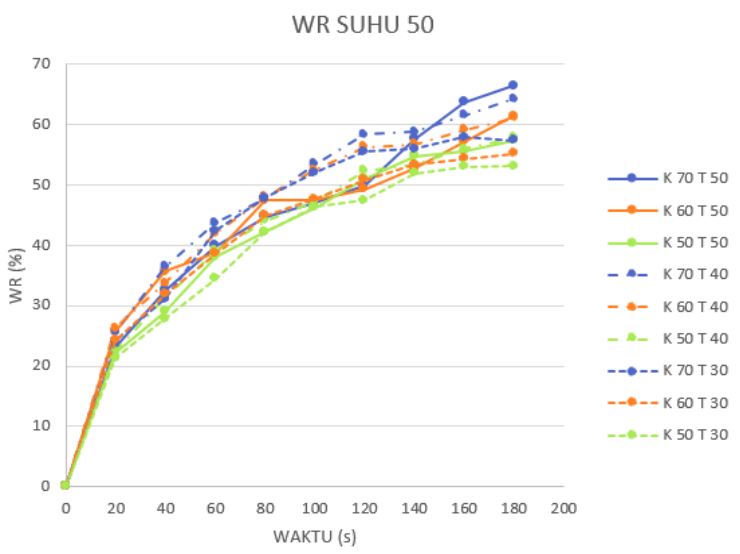

Gambar 3. Grafik hubungan WR dan Waktu

Pada Gambar 3. menunjukkan bahwa pada grafik hubungan WR dan waktu dapat dilihat untuk suhu $50^{\circ} \mathrm{C}$ yang ditandai dengan garis utuh peningkatan WR paling tinggi terjadi pada konsentrasi larutan 70 Brix dengan nilai $66,3 \%$, untuk suhu $40^{\circ} \mathrm{C}$ yang ditandai dengan garis dash dot peningkatan WR paling tinggi terjadi pada konsentrasi larutan 70 Brix dengan nilai $64,2 \%$, untuk suhu $30^{\circ} \mathrm{C}$ yang ditandai dengan garis putus putus peningkatan WR paling tinggi terjadi pada konsentrasi larutan 70 Brix dengan nilai $57,3 \%$. Untuk konsentrasi 70 Brix yang ditandai dengan garis berwarna biru peningkatan WR yang paling tinggi terjadi pada suhu $50^{\circ} \mathrm{C}$ dengan nilai $66,3 \%$, untuk konsentrasi 60 Brix yang ditandai dengan garis berwarna jingga peningkatan WR yang paling tinggi terjadi pada suhu $50^{\circ} \mathrm{C}$ dengan nilai $61,3 \%$, dan untuk konsentrasi 50 Brix yang ditandai dengan garis berwarna hijau peningkatan WR yang 
paling tinggi terjadi pada suhu $50^{\circ} \mathrm{C}$ dengan nilai $57,3 \%$, hal tersebut terjadi karena WR dipengaruhi oleh peningkatan suhu. Hal ini sesuai dengan pendapat Akbarian (2014), peningkatan konsentrasi larutan osmotik menyebabkan peningkatan pengurangan bobot. Hal ini dikaitkan dengan aktivitas air dari larutan osmotik yang menurun seiring dengan peningkatan zat terlarut dalam larutan.

\section{Solid Gain (SG)}

a. Hasil Penelitian untuk Solid Gain (SG)

Solid gain merupakan banyaknya padatan yang masuk ke dalam bahan dalam proses dehidrasi osmosis yang dinyatakan dalam persen. Adapun Tabel hasil untuk SG, seperti pada tabel di bawah:

\begin{tabular}{|c|c|c|c|c|}
\hline \multirow{2}{*}{$\begin{array}{c}\text { Suhu } \\
\text { Peren } \\
\text { daman } \\
\left({ }^{\circ} \mathrm{C}\right)\end{array}$} & \multicolumn{3}{|c|}{ Konsentrasi Larutan (Brix) } & \multirow{2}{*}{$\begin{array}{l}\text { Rata- } \\
\text { Rata }\end{array}$} \\
\hline & 50 & 60 & 70 & \\
\hline 30 & 0,4894 & 0,4378 & 0,5081 & 0,4784 \\
\hline 40 & 0,4597 & 0,6013 & 0,6245 & 0,5618 \\
\hline 50 & 0,7132 & 0,9453 & 1,0234 & 0,8940 \\
\hline $\begin{array}{l}\text { Rata- } \\
\text { Rata }\end{array}$ & 0,5541 & 0,6615 & 0,7186 & \\
\hline
\end{tabular}

Berdasarkan tabel 3 hasil penelitian untuk SG menunjukkan bahwa kombinasi perlakuan suhu perendaman $50^{\circ} \mathrm{C}$ dan konsentrasi larutan 70 Brix memiliki nilai SG yang paling tinggi. hal tersebut terjadi karena SG dipengaruhi oleh peningkatan suhu serta dipengaruhi oleh waktu perendaman. Hal ini sesuai dengan pernyataan Chavan (2012), proses dehidrasi osmosis yang ditetapkan pada suhu $50^{\circ} \mathrm{C}$ yang direndam dalam waktu 3 jam memberikan kehilangan air optimal dan masuknya gula ke dalam bahan optimal.

\section{b. Analisis Ragam untuk Solid Gain (SG) Berdasarkan hasil uji analisis ragam pada taraf 5\% untuk kadar air akhir menunjukkan bahwa ada interaksi antara konsentrasi larutan gula dan suhu perendaman dan memberikan pengaruh}

yang nyata terhadap adanya padatan yang masuk ke dalam bahan. Hal tersebut dilihat dari nilai signifikan suhu dan konsentrasi yang didapatkan yaitu 0,034 .

Berdasarkan hasil interaksi yang telah didapatkan bahwa nilai selisih dari kombinasi perlakuan yang nilainya lebih besar dari LSR yaitu suhu $50{ }^{\circ} \mathrm{C}$ konsentrasi 70 Brix berbeda nyata dengan kombinasi suhu $50{ }^{\circ} \mathrm{C}$ dan konsentrasi 50 Brix, suhu $40^{\circ} \mathrm{C}$ dan konsentrasi 70 konsentrasi Brix , suhu $40^{\circ} \mathrm{C}$ dan konsentrasi 60 Brix, suhu $30^{\circ} \mathrm{C}$ dan konsentrasi 70 Brix, suhu $30^{\circ} \mathrm{C}$ dan konsentrasi 50 Brix, suhu $50^{\circ} \mathrm{C}$ dan konsentrasi 50 Brix, dan suhu $30^{\circ} \mathrm{C}$ dan konsentrasi 60 Brix. Kombinasi perlakuan suhu $50^{\circ} \mathrm{C}$ dan konsentasi 60 Brix berbeda nyata dengan kombinasi suhu $50^{\circ} \mathrm{C}$ dan konsentrasi 50 Brix, suhu $40^{\circ} \mathrm{C}$ dan konsentrasi 70 konsentrasi Brix , suhu $40{ }^{\circ} \mathrm{C}$ dan konsentrasi 60 Brix, suhu $30^{\circ} \mathrm{C}$ dan konsentrasi 70 Brix, suhu $30^{\circ} \mathrm{C}$ dan konsentrasi 50 Brix, suhu $50{ }^{\circ} \mathrm{C}$ dan konsentrasi 50 Brix, dan suhu $30^{\circ} \mathrm{C}$ dan konsentrasi 60 Brix. Kombinasi perlakuan suhu $50^{\circ} \mathrm{C}$ dan konsentrasi 50 Brix berbeda nyata dengan kombinasi suhu $30^{\circ} \mathrm{C}$ dan konsentrasi 70 Brix, suhu $30^{\circ} \mathrm{C}$ dan konsentrasi 50 Brix, suhu $50^{\circ} \mathrm{C}$ dan konsentrasi 50 Brix, dan suhu $30^{\circ} \mathrm{C}$ dan konsentrasi 60 Brix. Kombinasi suhu $40{ }^{\circ} \mathrm{C}$ dan konsentrasi 70 Brix berbeda nyata dengan kombinasi suhu $40{ }^{\circ} \mathrm{C}$ dan konsentrasi 50 Brix dan $30^{\circ} \mathrm{C}$ dan konsentrasi 60 Brix. Kombinasi suhu $40^{\circ} \mathrm{C}$ dan konsentrasi 60 Brix berbeda nyata dengan kombinasi suhu $30^{\circ} \mathrm{C}$ dan konsentrasi 60 Brix. Untuk kombinasi lainnya yang tidak bergaris bawah nilai selisih yang didapatkan lebih kecil dari nilai LSR sehingga kombinasi tersebut tidak berbeda nyata 


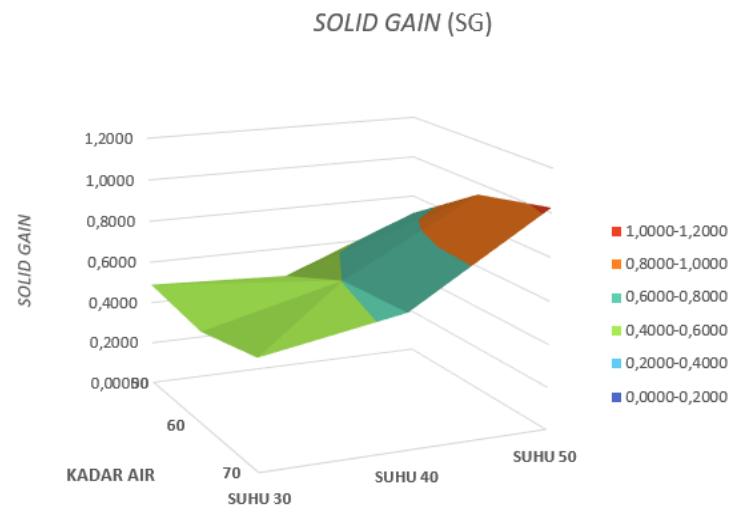

Gambar 4. Grafik Hubungan Suhu dan Konsentrasi terhadap SG

Pada gambar 4 menunjukkan bahwa pada grafik hubungan suhu dan konsentrasi terhadap masuknya padatan ke dalam bahan suhu $50^{\circ} \mathrm{C}$ padatan yang masuk ke dalam bahan paling banyak ada pada konsentrasi 70 Brix dengan nilai 1,0234 yang pada grafik ditunjukkan pada bagian berwarna merah. Sedangkan untuk kombinasi suhu $30^{\circ} \mathrm{C}$ dan konsentrasi 60 Brix menunjukkan padatan yang masuk ke dalam bahan paling sedikit dengan nilai 0,4378. Hal tersebut terjadi karena SG dipengaruhi oleh peningkatan suhu. Semakin tinggi suhu maka akan semakin tinggi pula padatan yang masuk ke dalam bahan. Hal ini sesuai dengan pernyataan Chavan (2012), Kehilangan air dan gula peningkatannya linier dengan peningkatan suhu dan konsentrasi gula. Konsentrasi gula dan suhu berfungsi dalam peningkatan defuse gula.

\section{Water Loss (WL)}

a. Hasil Penelitian untuk Water Loss (WL)

Water loss (WL) merupakan jumlah air yang hilang selama proses dehidrasi osmosis terjadi nilainya dinyatakan dalam persen. Adapun Tabel hasil untuk WL, seperti pada tabel di bawah:
Tabel 4. Hasil penelitian untuk pengukuran WL

\begin{tabular}{ccccc}
\hline $\begin{array}{c}\text { Suhu } \\
\text { Peren } \\
\text { daman } \\
\left({ }^{\circ} \mathrm{C}\right)\end{array}$ & 50 & 60 & 70 & $\begin{array}{c}\text { Konsentrasi Larutan (Brix) } \\
\text { Rata- } \\
\text { Rata }\end{array}$ \\
\hline 30 & 53,5353 & 55,6300 & 57,8430 & 55,6694 \\
40 & 58,1765 & 61,6429 & 64,8443 & 61,5546 \\
50 & 58,0662 & 60,3605 & 66,6635 & 61,6967 \\
\hline $\begin{array}{c}\text { Rata- } \\
\text { Rata }\end{array}$ & 56,5927 & 59,2111 & 63,1169 & \\
\hline
\end{tabular}

Berdasarkan tabel 4 hasil penelitian untuk WL menunjukkan bahwa kombinasi perlakuan suhu perendaman $50^{\circ} \mathrm{C}$ dan konsentasi larutan 70 Brix memiliki nilai kehilangan air yang paling tinggi. Hal tersebut terjadi karena penurunan air dalam bahan atau WL pada proses dehidrasi osmosis dipengaruhi oleh beberapa faktor dan salah satu sangat mempengaruhi adalah konsentrasi larutan. Hal ini sesuai dengan pendapat Jannah (2011), Laju kehilangan air dari jaringan produk dipengaruhi oleh beberapa faktor diantaranya suhu, komposisi dan konsentrasi larutan osmotik, karakteristik produk, perlakuan awal terhadap produk, ukuran dan bentuk geometri produk, tingkat pengadukan, dan lamanya proses pengeringan.

\section{b. Analisis Ragam untuk Water Loss (WL)}

Berdasarkan hasil uji analisis ragam pada taraf $5 \%$ menunjukkan bahwa interaksi antara konsentrasi larutan gula dan suhu perendaman tidak memberikan pengaruh yang nyata terhadap perubahan Water Loss (WL). Hal tersebut dilihat dari nilai signifikan yang didapatkan memiliki nilai 0,051 .

Setelah pengujian analisis ragam menunjukkan tidak adanya interaksi antara suhu dan konsentrasi larutan pada kehilangan air, maka dilakukan pengujian tersendiri terhadap suhu juga konsentrasi larutan dengan uji Duncan. Hasil pengujian Duncan pada taraf $5 \%$ untuk konsentrasi terhadap WL diperoleh konsentrasi 50 Brix berbeda nyata dengan 
konsentrasi 60 Brix dan 70 Brix. Untuk hasil pengujian Duncan pada taraf 5\% untuk suhu terhadap WL diperoleh untuk suhu $30^{\circ} \mathrm{C}$ berbeda nyata dengan suhu $40^{\circ} \mathrm{C}$ namun untuk konsentrasi $40^{\circ} \mathrm{C}$ dan suhu $50^{\circ} \mathrm{C}$ tidak berbeda nyata

WL SUHU 50

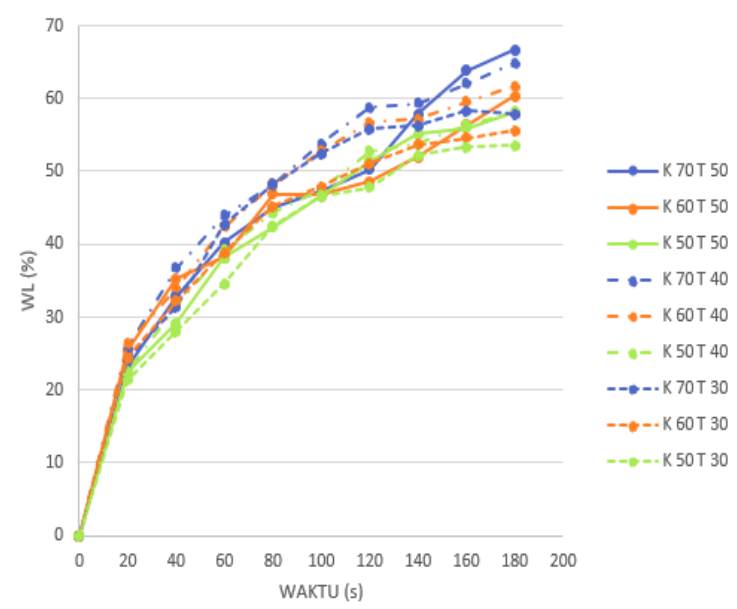

Gambar 5. Grafik hubungan WL dan waktu pada suhu $50^{\circ} \mathrm{C}$

Pada Gambar 5 menunjukkan bahwa pada grafik hubungan WL dan waktu untuk suhu $50^{\circ} \mathrm{C}$ yang ditandai dengan garis utuh peningkatan WL paling tinggi terjadi pada konsentrasi larutan 70 Brix dengan nilai $66,6 \%$, untuk suhu $40^{\circ} \mathrm{C}$ yang ditandai dengan garis dash dot peningkatan WR paling tinggi terjadi pada konsentrasi larutan 70 Brix dengan nilai $64,8 \%$, untuk suhu $30^{\circ} \mathrm{C}$ yang ditandai dengan garis putus putus peningkatan WL paling tinggi terjadi pada konsentrasi larutan 70 Brix dengan nilai 57,8\%. Untuk konsentrasi 70 Brix yang ditandai dengan garis berwarna biru peningkatan WL yang paling tinggi terjadi pada suhu $50^{\circ} \mathrm{C}$ dengan nilai $66,6 \%$, untuk konsentrasi 60 Brix yang ditandai dengan garis berwarna jingga peningkatan WL yang paling tinggi terjadi pada suhu $50^{\circ} \mathrm{C}$ dengan nilai $60,3 \%$, dan untuk konsentrasi 50 Brix yang ditandai dengan garis berwarna hijau peningkatan WL yang paling tinggi terjadi pada suhu $50^{\circ} \mathrm{C}$ dengan nilai $58 \%$, Hal tersebut dikarenakan peningkatan kehilangan air atau WL sejalan dengan peningkatan suhu pada proses perendaman. Hal ini sesuai dengan pernyataan Tortoe (2010), kenaikan suhu merupakan solusi untuk meningkatkan kehilangan air dalam osmosis.

\section{KESIMPULAN} ini yakni,

Adapun kesimpulan pada penelitian

1. Perlakuan suhu $50^{\circ} \mathrm{C}$ dan konsentrasi larutan osmosis $70 \quad$ Brix menghasilkan kadar air yang paling rendah yakni sebesar $33,8 \%$ basis basah.

2. Weight reduction (WR) paling tinggi pada penelitian ini berada pada kombinasi perlakuan suhu perendaman $50^{\circ} \mathrm{C}$ dan konsntrasi larutan 70 Brix begitu pula dengan water loss (WL).

3. Solid gain (SG) pada penelitian ini mempunyai peningkatan yang tertinggi, yakni sebesar 1,0234.

4. Pada penelitian ini, suhu dan konsentrasi memberikan pengaruh nyata terhadap kadar air akhir dan solid gain (SG) sedangkan pada peningkatan weight reduction (WR) dan water loss (WL) tidak memberikan pegaruh nyata.

\section{DAFTAR PUSTAKA}

Akbarian, M, Nila Ghasemkhani dan Fatemeh Moayedi. 2014. Osmotic dehydration of fruits in food industrial: A review. International Journal of Biosciences.

Chavan U.D. 2012. Osmotic Dehydration Process for Preservation of Fruit and Vegetables. Mahatma Phule Krishi Vidyapeeth; India.

Jannah, M. 2011. Pengeringan Osmotik Pada Irisan Buah Mangga Arumanis (Mangifera Indica L) dengan Pelapisan Kitosan. Institut Pertanian Bogor; Bogor. 
Kartika, P.N dan Fithri Choirun Nisa. 2015. Studi Pembuatan Osmodehidrat Buah Nanas (Ananas Cosmosus L. Merr): Kajian Konsentrasi Gula Dalam Larutan Osmosis dan Lama Perendaman. Universitas Brawijaya: Malang.

Sharma, S.K., Steven J.M. and Syed S.H.R. 2000. Food Process Engineering: Theory and Laboratory Experiments. Wiley-Interscience: New York.

Tortoe, C. 2010. A Review of Osmodehydration For Food Industry. Food Research InstituteCouncil for Scientific and Industrial Reserch; Ghana.

Wongsowijoyo, Suryadi. 2014. UmbiUmbi Berkhasiat Obat. PT. Leutika Nouvalitera: Yogyakarta. 